\title{
ROLE OF INDOLE ACETIC ACID ON GROWTH AND BIOMASS PRODUCTION OF ATHEL TREE (TAMARIX APHYLLA) BY USING DIFFERENT CUTTING LENGTHS
}

\author{
RASHID, M. H. U. ${ }^{1,3,4 \dagger}-$ FAROOQ, T. H. ${ }^{2 \dagger}-$ IQBAL, W. ${ }^{4}-$ ASIF, M. ${ }^{4}-$ ISLAM, W. ${ }^{5}-$ LIN, D. C. ${ }^{1,3}$ \\ - AHMAD, I. ${ }^{4}-$ WU, P. F. ${ }^{1,3 *}$ \\ ${ }^{1}$ Forestry College, Fujian Agriculture and Forestry University, Fuzhou 350002, Fujian \\ Province, PR China \\ ${ }^{2}$ College of Life Science and Technology, National Engineering Laboratory for Applied \\ Technology of Forestry \& Ecology in South China, Central South University of Forestry and \\ Technology, Changsha 410000, Hunan Province, PR China
}

${ }^{3}$ Fujian Provincial Colleges and University Engineering Research Center of Plantation Sustainable Management, Fujian Agriculture and Forestry University, Fuzhou 350002, Fujian Province, PR China ${ }^{4}$ Department of Forestry and Range Management, University of Agriculture, Faisalabad
38000, Punjab Province, Pakistan

${ }^{5}$ Institute of Geography, Fujian Normal University, Fuzhou 350007, Fujian Province, PR China

${ }^{T}$ These authors contributed equally to this work

*Corresponding author

e-mail: fjwupengfei@126.com,fjwupengfei@fafu.edu.cn; phonelfax: +86-591-8378-0261

(Received 6 ${ }^{\text {th }}$ Sep 2019; accepted $11^{\text {th }}$ Feb 2020)

\begin{abstract}
Forests play a vital role in supporting life on earth. Diversification in industrialization, urbanization and overpopulation make it challenging to eliminate the impurities from the environment and to conserve our flora and fauna for basic ecological services. To enhance forest cover and growth of a plant, vegetative propagation plays a vital role. Cuttings are important plant parts that affect the growth of the plant in asexual propagation. This study aimed to observe growth response and biomass production of Tamarix aphylla with and without Indole-3-acetic acid (IAA) treatments at different cutting lengths. By analyzing the effect of IAA, different morphological factors were observed such as root, shoot and leaves fresh and dry weight, whole plant biomass, root and shoot length, root to shoot ratio and moisture content availability. Results showed that by increasing the cutting lengths, the growth of cuttings increased by applying IAA treatment. Overall, IAA produced a positive effect on $T$. aphylla cuttings growth as compared to IAA non-treated. According to the findings, indole acetic is a worthwhile option to get a good quality of seedling production. For that reason, understanding of this mechanism can help to make future decisions for plant growth and biomass production.
\end{abstract}

Keywords: vegetative propagation, morphology, growth hormone application, tree production

\section{Introduction}

Pakistan has a unique combination of ecological zones like deserts, plains, and the coastal line. Generally, Pakistan has arid subtropical weather conditions and it possesses a considerable variation of annual rainfall (Hussain et al., 2003). In recent years Pakistan is facing a severe shortage of timber and firewood, and only $10 \%$ timber requirement are 
fulfilled by state forests, whereas $90 \%$ are met by the farmlands. Therefore, to supplement production from the state forests trees on-farm has been making a handsome contribution.

Moreover, agroforestry techniques are playing a crucial role to fulfill our wood requirement. Tamarix aphylla belongs to a genus of family Tamaricaceae, and largest known species of Tamarix. It consists of 54 native species and mainly present in the Pakistan, Iran, Afghanistan, Kazakhstan, China, some parts of Turkmenistan and Mediterranean areas. Moreover, it is spread widely throughout Europe and Africa (Orwa et al., 2009). In the form of shrub, mainly it is found at beaches, coastal areas and islands. A reasonable size of an evergreen tree of almost $18 \mathrm{~m}$ height has resistance to sudden shock. It's hard, close grained, fibrous wood has very good mechanical properties. (Orwa et al., 2009).

Via seed germination, expected plant propagation is not possible on a sustainable basis that is the basic and potential advantage of vegetative propagation. However, due to the physiological factor like age of the parent plant, plant raised via vegetative propagation uphold a specific propagation period earlier than flowering. There is a risk that soon after flowering propagation death of a plant could occur (Banik, 1985), environmental factors that may change such status.

Several times, factors responsible for successful macro propagation of cuttings are internal or external, respectively. Many of these domestic and superficial causes are accountable for the successful propagation with cuttings, age of a parent plant (Saharia and Sen, 1990), cutting type (Singh et al., 2011), setting of propagation mode, specific concentration and type of plant growth hormones (Singh et al., 2012), season of propagation (Singh et al., 2011; Chhetri and Kumar, 2015) and material which is used in propagation (Ray and Ali, 2016, 2017) etc. With the addition of external factors like the intensity of heat present (Senyanzobe et al., 2013), balance of water, channel for rooting, intensity of light, pest and diseases attack, wind speed and humidity factors for limiting macro propagation (Banik, 1985).

Vegetative propagation practice of 1-year old cutting in different tree plants has been done, such as Bambusa balcooa (Gantait et al., 2018), 1.5-year old for B. vulgaris (Bhol and Nayak, 2012), 2-year old for B. vulgaris (Senyanzobe et al., 2013), A. alpine (Senyanzobe et al., 2013), O. abyssinica (Elbasheer and Raddad, 2013). Islam et al (2011), reported successful vegetative propagation of $B$. vulgaris, and found that immature cuttings are considered foremost appropriate due to the presence of extremely vigorous buds, which plays a crucial role in macro propagation (Elbasheer and Raddad, 2013). Plenty of queries have been carried out by various researchers to find out the influence of different lengths of cuttings on survival rate and growth of seedlings of various trees (Rashid et al., 2018).

The purpose of the study is to observe the response of different cutting lengths of $T$. aphylla under Indole-3-acetic acid (IAA) to check their survival and growth as well as biomass production. In this experiment, T. aphylla was selected because of its importance for timber, fuelwood; provide high-value forage, good salt absorption ability, and other nontangible benefits. It can successfully grow in different areas in both tree and shrub form with diverse soil moisture contents.

\section{Materials and methods Site description}

The proposed study was carried out in the experimental area of the Department of Forestry and Range Management, University of Agriculture Faisalabad, Punjab, 
Pakistan (Fig. 1). The site was located at the latitude of $36^{\circ}-26^{\circ} \mathrm{N}$ and longitude of $73^{\circ}-06^{\circ} \mathrm{E}$ with an altitude of $184 \mathrm{~m}$.

During the whole experimental period, weather conditions were recorded from agricultural meteorology cell, University of Agriculture, Faisalabad. Weather condition of the study site reported in Table 1, while the information about soil physical and chemical properties mentioned in Table 2. Weather data about average temperature, average rainfall, relative humidity, average sunshine and wind speed at site mentioned for six months due to the total length of experiment.

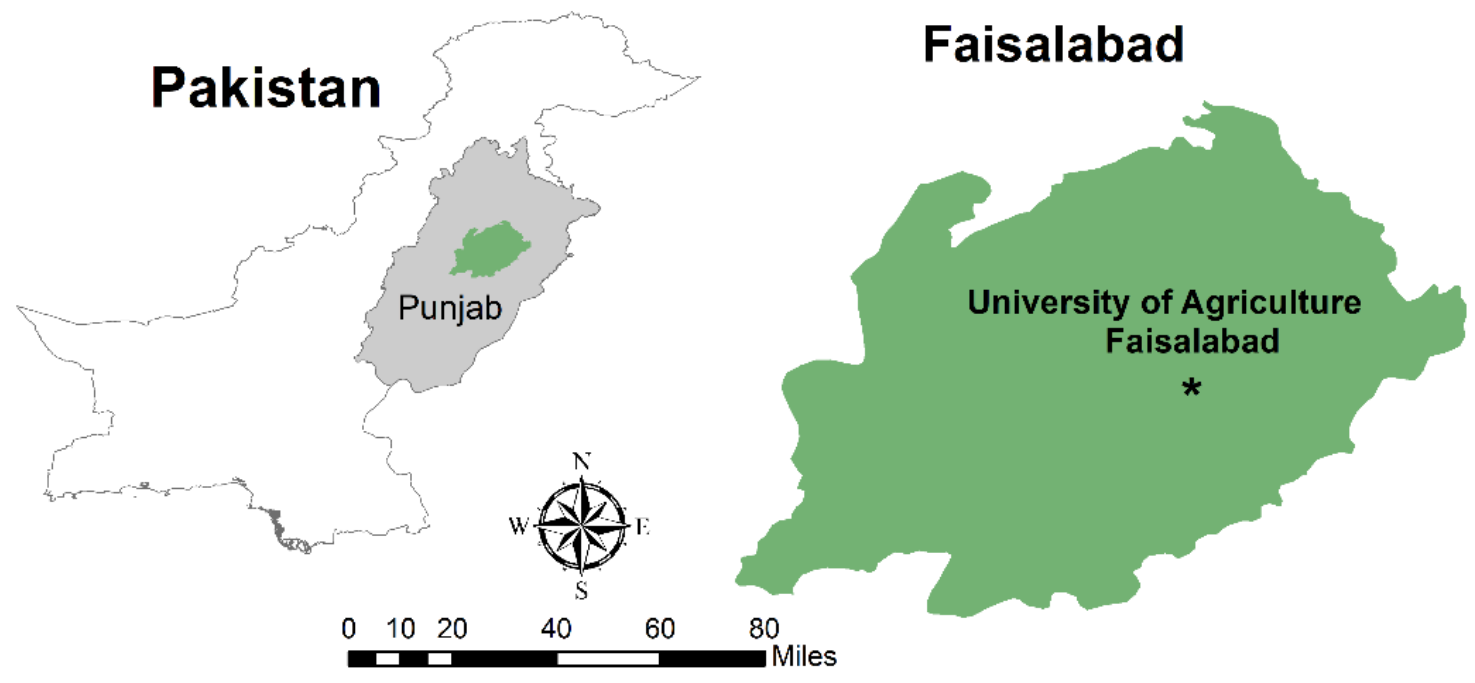

Figure 1. Location of the experimental site (University of Agriculture Faisalabad)

Table 1. Weather condition of the study site (Agromet bulletin, Agricultural meteorology cell, University of Agriculture Faisalabad). Six-month experiment conducted from February 2019 to July 2019

\begin{tabular}{|c|c|c|c|c|c|c|c|}
\hline \multirow{2}{*}{ Month } & \multicolumn{3}{|c|}{ Temperature } & \multirow{2}{*}{$\begin{array}{l}\text { R.H } \\
(\%)\end{array}$} & \multirow{2}{*}{$\begin{array}{c}\text { Rainfall } \\
(\mathbf{m m})\end{array}$} & \multirow{2}{*}{$\begin{array}{l}\text { Sunshine } \\
\text { (h) }\end{array}$} & \multirow{2}{*}{$\begin{array}{l}\text { Wind speed } \\
(\mathbf{K m} / \mathbf{h})\end{array}$} \\
\hline & $\operatorname{Max}\left({ }^{\circ} \mathbf{C}\right)$ & $\operatorname{Min}\left({ }^{\circ} \mathbf{C}\right)$ & $\operatorname{Avg}\left({ }^{\circ} \mathrm{C}\right)$ & & & & \\
\hline February & 24.0 & 9.5 & 16.7 & 73.3 & 9.5 & 6.5 & 3.8 \\
\hline March & 31.2 & 16.4 & 23.8 & 61.4 & 12.5 & 8.6 & 5.2 \\
\hline April & 36.8 & 20.8 & 28.8 & 47.3 & 7.9 & 9.1 & 3.1 \\
\hline May & 40.3 & 23.7 & 32.0 & 29.8 & 21.6 & 8.6 & 3.4 \\
\hline June & 39.8 & 27.9 & 33.9 & 56.5 & 92.0 & 9.3 & 4.3 \\
\hline July & 38.0 & 28.0 & 33.0 & 70.2 & 195.8 & 7.9 & 5.2 \\
\hline
\end{tabular}

Table 2. Soil physical and chemical properties of experimental site

\begin{tabular}{c|c|c|c|c|c|c|c|c|c|c}
\hline Parameters & $\begin{array}{c}\text { Sand } \\
(\boldsymbol{\%})\end{array}$ & $\begin{array}{c}\text { Silt } \\
(\boldsymbol{\%})\end{array}$ & $\begin{array}{c}\text { Clay } \\
(\boldsymbol{\%})\end{array}$ & $\mathbf{p H}$ & $\begin{array}{c}\mathbf{E C} \\
\left(\mathbf{d S m}^{-\mathbf{1}}\right)\end{array}$ & $\begin{array}{c}\text { TSS } \\
(\mathbf{p p m})\end{array}$ & $\begin{array}{c}\mathbf{N} \\
(\boldsymbol{\%})\end{array}$ & $\begin{array}{c}\mathbf{P} \\
(\mathbf{p p m})\end{array}$ & $\begin{array}{c}\mathbf{K} \\
(\mathbf{p p m})\end{array}$ & $\begin{array}{c}\text { Organic } \\
\mathbf{m a t t e r}(\boldsymbol{\%})\end{array}$ \\
\hline $0-20 \mathrm{~cm}$ & 37 & 42 & 13 & 8.0 & 1.54 & 1176 & 0.068 & 3.6 & 280 & 1.43 \\
$20-40 \mathrm{~cm}$ & 66 & 15.5 & 10.5 & 8.1 & 1.21 & 1236 & 0.04 & 9.4 & 250 & 0.87 \\
\hline
\end{tabular}




\section{Experimental design}

Sunken beds were prepared in the usual way by making them weed-free and loosening of soil by having a sandy clay loam texture, at the forest nursery of Department of Forestry and Range Management, University of Agriculture, Faisalabad (Fig. 2). From the mature tree of T. aphylla, different sizes of cuttings were prepared, from the Punjab Forestry Research Institute(PFRI), Gutwala, Faisalabad, Pakistan. Duration of this experiment was six months. IAA and non-IAA treatments with four cutting lengths were used with the ten replications for each treatment. Half number (forty) of cuttings were treated with the solution of IAA $(5000 \mathrm{ppm})$ dose (Guney et al., 2016), while the other half were untreated. Overall, 80 pots (40 each for both IAA and non-IAA treatment) were used in the experiment (Fig. 2). Information about cutting lengths is given below:

1. T1 (15.24 cm cutting length of Tamarix aphylla)

2. T2 $(22.86 \mathrm{~cm}$ cutting length of Tamarix aphylla)

3. T3 (30.48 cm cutting length of Tamarix aphylla)

4. T4 (38.10 cm cutting length of Tamarix aphylla)

The experiment was laid out in Completely Randomized Design (CRD). Daily observation was made but measurements were taken at the end of the trial. Concluding observations were taken on the $10^{\text {th }}$ of July, 2019.

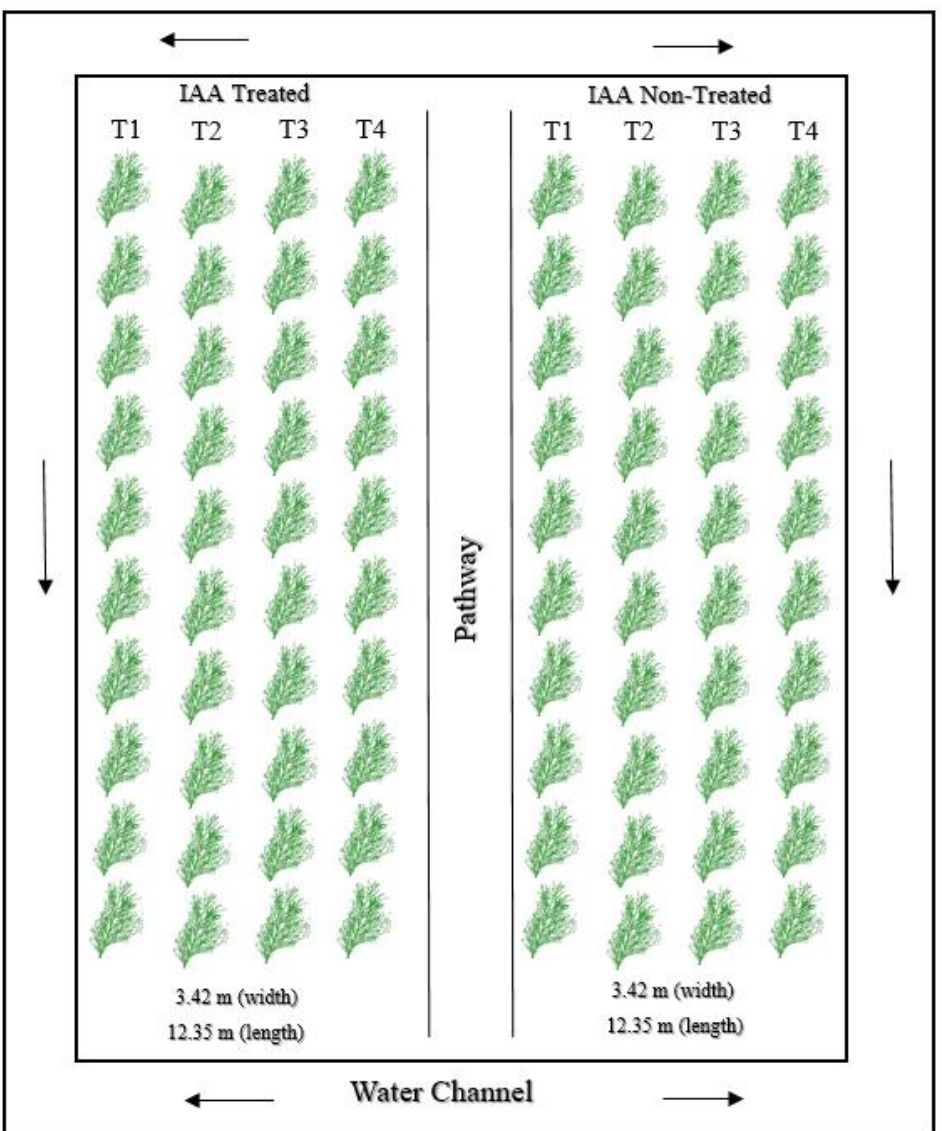

Figure 2. Layout of the experimental design (T1,T2, T3 and T4 are cutting of $15.24 \mathrm{~cm}$, $22.86 \mathrm{~cm}, 30.48 \mathrm{~cm} 38.10 \mathrm{~cm}$ lengths, respectively) 


\section{Cutting transplanting}

Planting rod was used for transplanting the cuttings of $T$. aphylla in two blocks, 1 : IAA treated and 2: IAA non-treated. Cuttings planted in the mid of February 2019 to analyze the hormonal effect on the morphological characteristics of different size of cuttings. Irrigation was given immediately after planting the cuttings.

\section{Harvesting and observed parameters}

Root length and stem height, root, stem and leaves fresh and dry weight, whole plant biomass, root-shoot ratio and moisture content availability were measured. Measured plant age was almost 6 months at the time of harvesting. The sampled plants were felled and the roots were excavated by digging up to the maximum root depth. In field, the soil was removed from the roots by hand to take the fresh weight. Then the samples were brought to the laboratory for further processing. In lab, root samples were oven dried for the calculation of biomass produced. The length of shoot was measured with measuring tape while the root length was measured with a meter rod and then average was calculated to express mean length of the whole plant. For mean length, plant per block average calculated. Cuttings average were taken under each treatment for both factors with the application of IAA and without applying IAA. While recording the dry weight; material was put into the paper bags and oven dried at $75^{\circ} \mathrm{C}$ for $24 \mathrm{~h}$ and then weighed with the help of electrical balance.

\section{Statistical analysis}

Two-way ANOVA was used to observe the interaction between IAA and cutting length and showed significant differences when compared by using Tukey's test. Statistical analyses were conducted using SPSS Statistical Package (SPSS 17.0, SPSS Ins., IL, USA). Results were statistically analyzed using a $\mathrm{P}<0.05$ level of significance.

\section{Results}

\section{Plant morphological growth}

Cutting length had a significant effect on the morphological growth of root and shoot. Conferring to our results, highly significant $(\mathrm{P}<0.05)$ variations among different cutting levels in both treatments were observed. Stem height was observed higher in T4 IAA treated cuttings with $42.79 \pm 1.02 \mathrm{~cm}$ as compared to non-treated where maximum height was $37.40 \pm 1.4 \mathrm{~cm}$ (Fig. 3). In comparison of hormone treatment, all the cutting treated with IAA growth showed better shoot growth in their respective lengths as compare to plants, which were un-treated. Overall, in terms of stem height, T4 cutting responded much better as compare to other cuttings in both IAA treated and non-treated cuttings.

Similarly, in root length T4 cutting responded better and it was higher with the value of $27.84 \pm 1.6 \mathrm{~cm}$ in IAA treated cuttings and $23.12 \pm 1.7 \mathrm{~cm}$ in non-treated plants, while in stem height the same pattern was observed. Root length and stem height consistently increased as the cutting length increased and IAA treated cutting lengths show better growth as compare to IAA non-treated plants among all cutting lengths (Fig. 3). 


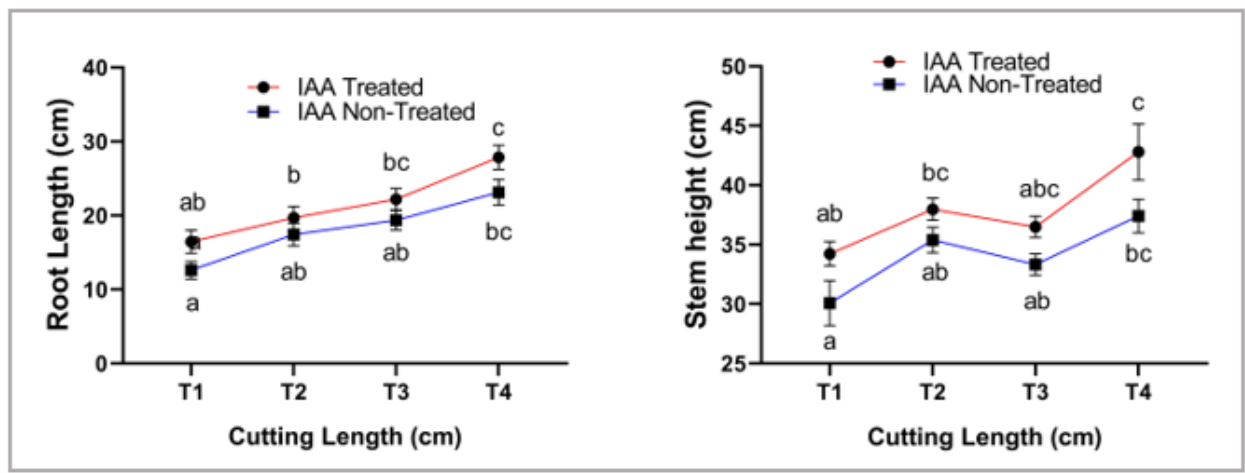

Figure 3. Average root and stem length under different sized cuttings treated with IAA hormone and non-treated cuttings. (T1, T2, T3 and T4 are cutting of $15.24 \mathrm{~cm}, 22.86 \mathrm{~cm}$, and $30.48 \mathrm{~cm}$ $38.10 \mathrm{~cm}$ lengths, respectively)

\section{Fresh biomass of plant organs}

Root fresh weight increased from $8.1 \pm 0.6$ to $15.25 \pm 1.55 \mathrm{gm}$ in cutting treated with IAA and it was found highest in T4 cutting and lowest in T1 cutting. Moreover, same pattern was observed in non-treated IAA plants. In comparison of hormonal application, it was highest in IAA treated plants.

Among all treatments of cutting lengths and hormone application, stem fresh weight was also observed highest in T4 cutting treated with IAA application $(37.2 \pm 3.16 \mathrm{~g})$, similarly, leaves fresh weight was also observed highest in T4 cutting treated with IAA application $(15.5 \pm 1.23 \mathrm{~g})$. Overall, fresh weight of all organs like root, stem and leaves increased consistently as the cutting lengths increased both in treated and untreated plants but it was highest in the IAA treated plants (Fig. 4).

\section{Dry biomass of plant organs}

According to statistical analysis, a significant difference $(P<0.05)$ was observed in the dry biomass distribution of different plant organs among IAA treated and nontreated cuttings. Root dry biomass was observed highest in T4 and lowest in T2 in both IAA treated and non-treated cuttings. However, in hormonal application comparison it was observed highest in cutting which was treated with IAA. In cuttings lengths comparison, it consistently increased as the cutting length increased in both IAA and treated cuttings.

Stem dry biomass increased in T4 cuttings and it was observed $18.25 \pm 0.7 \mathrm{~g}$ in the cuttings which were treated with IAA hormone as compare to un-treated cutting where it was $7.75 \pm 0.7 \mathrm{~g}$ and it decreased to $4.25 \pm 0.3 \mathrm{~g}$ and $6.75 \pm 0.3 \mathrm{~g}$, respectively in $\mathrm{T} 1$ cuttings. Same as stem, in leaves higher biomass value was observed in T4 cuttings $(8.125 \pm 0.7 \mathrm{~g})$ where it was treated with IAA and as compare to non-treated cuttings (Fig. 5).

\section{Root shoot ratio}

The root-shoot ratio showed a significant difference $(P=0.002)$ among different treatments. Highest root shoot ratio in terms of biomass production was found in T1 cuttings of both IAA treated and not treated, while lowest was observed in T2 cuttings. In terms of IAA hormonal application and non-application comparison, root shoot ratio 
was highest in non-treated cutting with the value of $(0.6443 \pm 0.08)$ as compare to IAA treated plants $(0.6270 \pm 0.01)$, in T1 cuttings (Fig. 6).

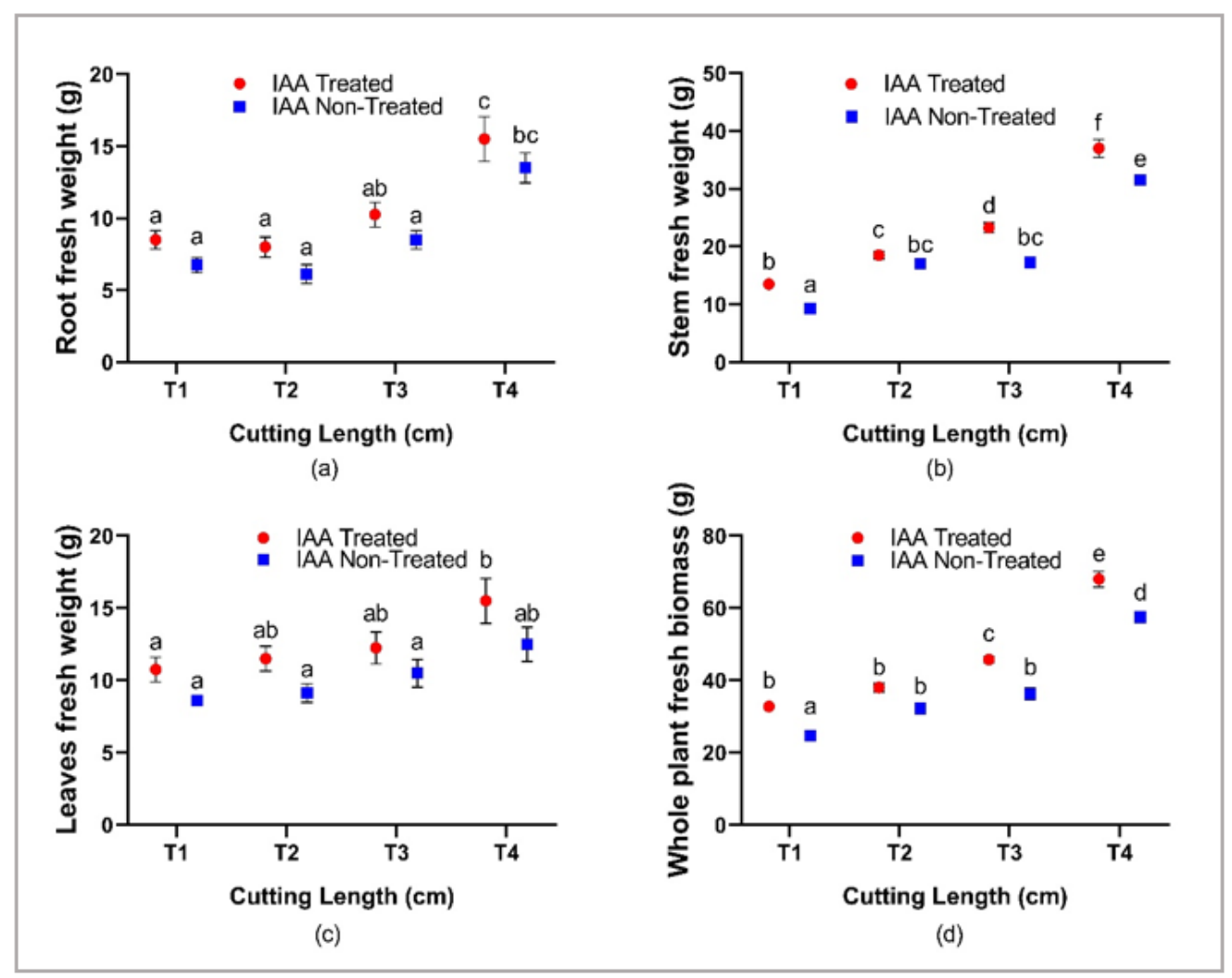

Figure 4. (a) Root fresh biomass, (b) stem fresh biomass, (c) leaves fresh biomass and (d) whole plant fresh biomass of different cutting lengths treated with IAA treated and non-treated cuttings

\section{Moisture content availability}

Moisture content availability showed non-significant results between IAA treated and non-treated cutting, same as with cutting lengths $(\mathrm{P}=0.352)$ (Fig. 7).

\section{Interaction between IAA and cutting length}

Under two-way ANOVA analysis, the interaction between IAA and cutting length showed a non-significant behavior in our results (Table 3).

Table 3. $P$ values of ANOVA of morphological growth parameters, biomass production and moisture content availability

\begin{tabular}{c|c|c|c|c|c|c|c|c|c}
\hline \multirow{2}{*}{ Factors } & df & \multicolumn{10}{|c}{ P-value and significance level } \\
\cline { 3 - 10 } & & $\begin{array}{c}\text { Root dry } \\
\text { weight }\end{array}$ & $\begin{array}{c}\text { Stem dry } \\
\text { weight }\end{array}$ & $\begin{array}{c}\text { Leaves dry } \\
\text { weight }\end{array}$ & $\begin{array}{c}\text { Whole-plant } \\
\text { biomass }\end{array}$ & $\begin{array}{c}\text { Root shoot } \\
\text { ratio }\end{array}$ & $\begin{array}{c}\text { Root } \\
\text { length }\end{array}$ & $\begin{array}{c}\text { Stem } \\
\text { height }\end{array}$ & $\begin{array}{c}\text { Moisture content } \\
\text { availability }\end{array}$ \\
\hline IAA & 1 & $0.005^{* * *}$ & $<0.001 * * *$ & $0.001 * * *$ & $<0.001 * * *$ & $<0.709 \mathrm{NS}$ & $<0.007 * * *$ & $0.001 * * *$ & $<0.709 \mathrm{NS}$ \\
\hline Cutting length & 3 & $<0.001 * * *$ & $<0.001 * * *$ & $<0.001 * * *$ & $<0.001 * * *$ & $<0.042^{*}$ & $<0.001 * * *$ & $<0.001 * * *$ & $<0.302 \mathrm{NS}$ \\
\hline $\begin{array}{c}\text { IAA } \times \text { cutting } \\
\text { length }\end{array}$ & 3 & $0.632 \mathrm{NS}$ & $<0.089 \mathrm{NS}$ & $0.899 \mathrm{NS}$ & $<0.151 \mathrm{NS}$ & $<0.453 \mathrm{NS}$ & $0.841 \mathrm{NS}$ & $0.789 \mathrm{NS}$ & $<0.201 \mathrm{NS}$ \\
\hline
\end{tabular}

Significance of analysis of variance factor: NS: non-significant, $* \mathrm{P}<0.05$, ** $\mathrm{P}<0.01$, *** $\mathrm{P}<0.001$ 


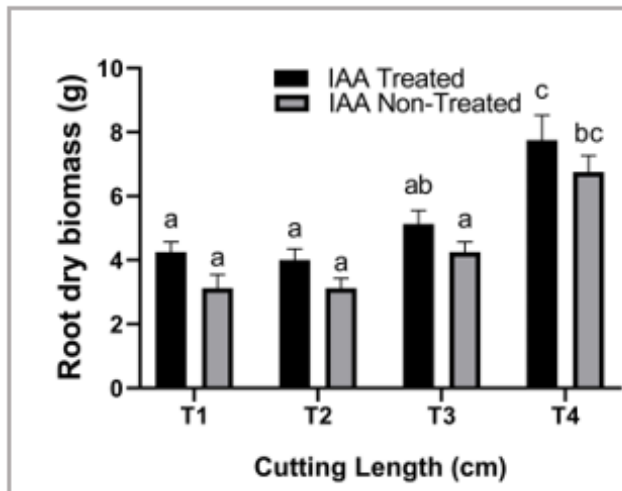

(a)

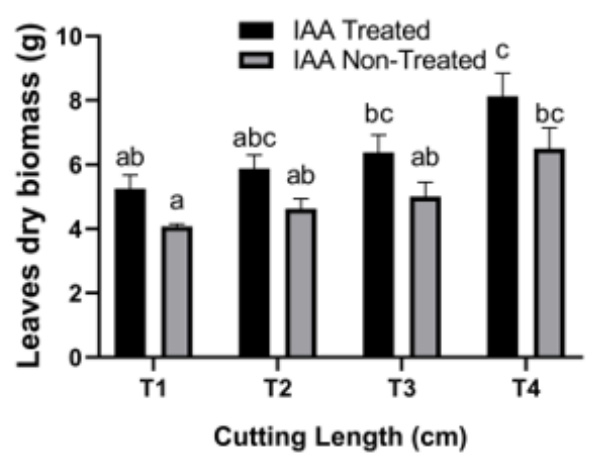

(c)

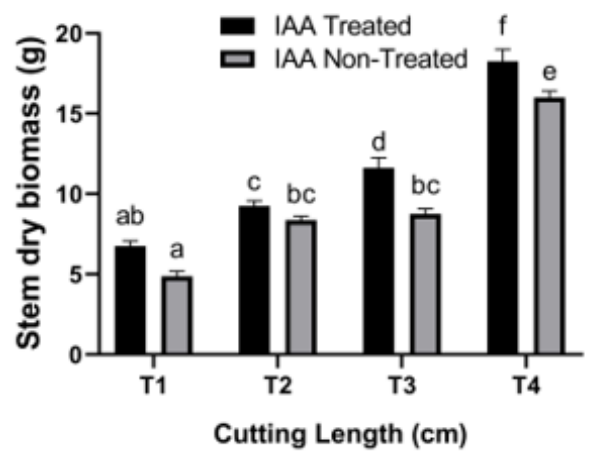

(b)

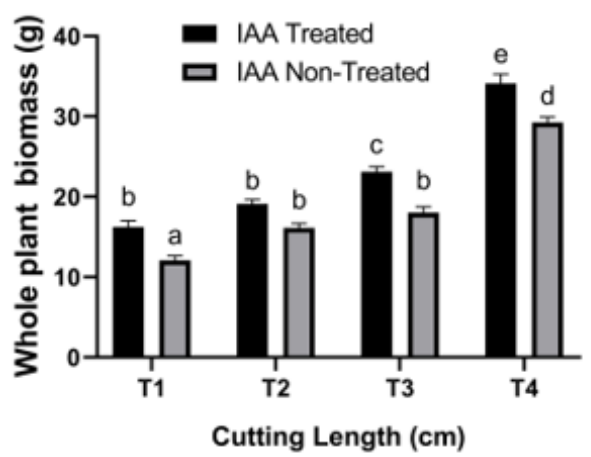

(d)

Figure 5. (a) Root dry biomass, (b) stem dry biomass, (c) leaves dry biomass, and (d) whole plant dry biomass of different cutting lengths treated with IAA treated and non-treated

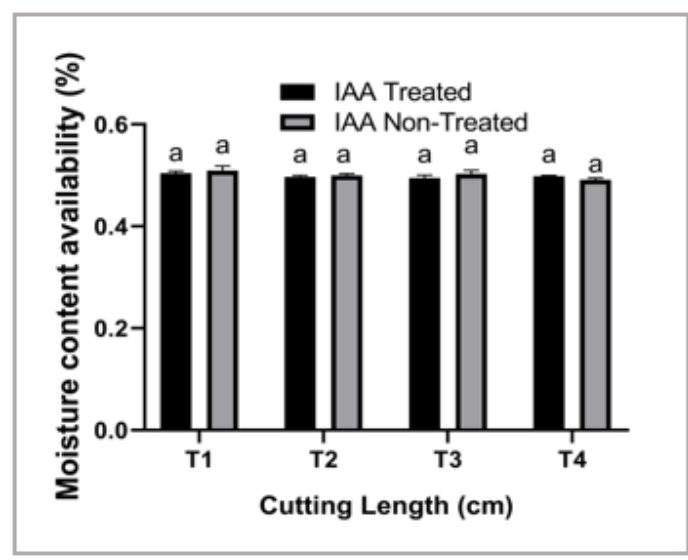

Figure 6. Root shoot ratio of different cutting length treated with IAA and non-treated cuttings

\section{Discussion}

Plant development is controlled by different environmental aspects, which directly influence plant morphological and physiological growth (Rashid et al., 2018). IAA is the main hormones in plants which play a direct role in plant growth, having an intricate pattern of active transport (Gehlot et al., 2014). In cuttings, auxins enter through the cut 
surface area. Auxin helps to maintain the divergence of growth in plants and distinguish the connection of plants organs (Rahbin et al., 2012). The stimulatory effect of IAA was observed on morphological traits of $T$. aphylla. IAA showed a significant difference on T4 cuttings, which attributed in root and shoot weight, root and shoot length, and root to shoot ratio.

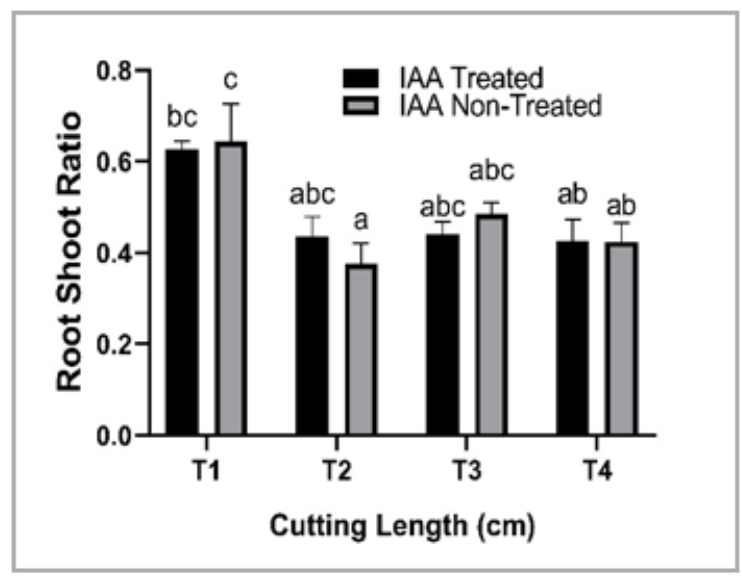

Figure 7. Moisture content availability of different cutting length treated with IAA and nontreated cuttings

IAA was suitable to stem cuttings in encouraging the morphological growth. According to our analysis of variance, results showed that IAA increased all traits significantly compared to IAA non-treated as in the work of (Singh et al., 2012; Mohana et al., 2014). The application of IAA persuades root growth on leafy cuttings is widely predictable (Husen and Pal, 2007). IAA has a direct effect on the root system, enhancing their ability to thrive for better growth (Sevik and Guney, 2013; Reena et al., 2012; Štefančič et al., 2005; Nordström et al., 1991). It indicates that IAA had a positive effect on the root development success of cuttings (Trobec et al., 2005). As also described by our results that IAA concentration significantly impacted root and shoot lengths and these were maximum in $\mathrm{T} 4$ cuttings of $T$. aphylla. These findings are partially agreed with the work of (Khan et al., 2006), who proved that auxins help to enhance vegetative growth of a plant. The stimulation of adventitious roots through different environmental and endogenous factors like temperature, light, sugar and IAA applications reported by (Pop et al., 2011). To achieve vigorous rooting optimum environmental conditions required, which help in the plant morphological and physiological growth (Sevik and Cetin, 2016).

Biomass production of $T$. aphylla showed a significant difference among IAA concentration in our studies, the plant showed a vigorous growth with T4 cuttings as compared to other cuttings both with IAA and IAA non-treated but was higher in IAA treated in their respective comparison which agrees with the results of (Sorin et al., 2005; Khudhur and Omer, 2015).

As IAA participates in different developmental processes of plants growth, from a cellular level to structural and eventually, the whole plant (Pandey et al., 2011) So, it was also quite clear that the growth of $T$. aphylla with T4 cutting with a cutting length of 15 was much better under the effect of IAA. 


\section{Conclusion}

Plantation of T. aphylla is a sustainable option for good quality of timber production and is one of the fast-growing tree plants with a reasonable size having high resistance to sudden shock. Different applications of IAA had a significant effect on the morphological growth of $T$. aphylla. IAA was very beneficial to plant growth and development. Overall positive impact of IAA on different morphological traits and biomass production of $T$. aphyllawas observed. It was concluded that by the optimal application of IAA, we can enhance the growth of T. aphylla.

Acknowledgments. This study was financially supported by the Science and Technology Major Project of Fujian Province (2018NZ0001-1) and the Special Technology Innovation Foundation of Fujian Agriculture and Forestry University (CXZX2018134). As well as we are thankful to Endowment fund, funded project (TT113/16).

Conflict of interests. Authors declare that there is no conflict of interests.

\section{REFERENCES}

[1] Banik, R. L. (1985): Techniques of Bamboo Propagation with Special Reference to Prerooted and Pre-rhizomed Branch Cuttings and Tissue Culture. - In: Rao, A. N. et al. (eds.) Proc. International Bamboo Workshop, Hangzhou, China, 6-14 October 1985. IDRC, Canada, pp. 160-169.

[2] Bhol, N., Nayak, H. (2012): Effect of planting alignment and cutting size on propagation of Bambusa vulgaris. - Journal of Tree Sciences 31(1-2): 69-75.

[3] Chhetri, S., Kumar, H. (2015): Effect of planting position on rhizogenesis in Buddha belly bamboo (Bambu saventricosa) under nursery condition. - Journal of International Academic Research for Multidisciplinary 2(12): 283-289.

[4] Elbasheer, Y. H. A., Raddad, E. A. Y. (2013): Vegetative propagation of (Oxytenanthera abyssinica) by culm cuttings. - Journal of Natural Resources and Environmental Studies 1(3): $1-5$.

[5] Gantait, S., Pramanik, B. R., Banerjee, M. (2018): Optimization of planting materials for large scale plantation of Bambusa balcooa Roxb.: Influence of propagation methods. Journal of the Saudi Society of Agricultural Sciences 17(1): 79-87.

[6] Gehlot, A., Gupta, R. K., Tripathi, A., Arya, I. D., Arya, S. (2014): Vegetative propagation of Azadirachta indica: effect of auxin and rooting media on adventitious root induction in mini-cuttings. - Advances in Forestry Science 1(1): 1-9.

[7] Guney, K., Cetin, M., Sevik, H., Guney, K. B. (2016): Influence of germination percentage and morphological properties of some hormones practice on Lilium martagon L. seeds. - Oxidation Communications 39(1): 466-474.

[8] Husen, A., Pal, M. (2007): Metabolic changes during adventitious root primordium development in Tectona grandis Linn. f.(teak) cuttings as affected by age of donor plants and auxin (IBA and NAA) treatment. - New Forests 33(3): 309-323.

[9] Hussain, S. S., Arshad, M. K., Shahzad, A. M. (2003): Mountains of Pakistan: Protection, Potential and Prospects. - Global Change Impact Studies Centre, Islamabad, pp. 133-232.

[10] Islam, M. S., Bhuiyan, M. K., Hossain, M. M., Hossain, M. A. (2011): Clonal propagation of Bambusa vulgaris by leafy branch cuttings. - Journal of Forestry Research 22(3): 387-392.

[11] Khan, M. S., Khan, R. U., Waseem, K. A. S. H. I. F. (2006): Effect of some auxins on growth of damask rose cuttings in different growing media. - Journal of Agriculture \& Social Sciences 2(1): 13-16. 
[12] Khudhur, S. A., Omer, T. J. (2015): Effect of NAA and IAA on stem cuttings of Dalbergia sissoo (Roxb). - Journal of Biology and Life Science 6(2): 208-220.

[13] Mohana, M., Majd, A., Jafari, S., Kiabi, S., Paivandi, M. (2014): The effect of various concentrations of Iba and Naa on the rooting of semi hardwood cuttings of Azalea alexander L. - Advances in Environmental Biology 8(7): 2223-2231.

[14] Nordström, A. C., Jacobs, F. A., Eliasson, L. (1991): Effect of exogenous indole-3-acetic acid and indole-3-butyric acid on internal levels of the respective auxins and their conjugation with aspartic acid during adventitious root formation in pea cuttings. - Plant Physiology 96(3): 856-861.

[15] Orwa, C., Mutua, A., Kindt, R., Jamnadass, R., Simons, A. (2009): Agroforestree Database: A Tree Reference and Selection Guide. Version 4. - World Agroforestry Centre, Kenya.

[16] Pandey, A., Tamta, S., Giri, D. (2011): Role of auxin on adventitious root formation and subsequent growth of cutting raised plantlets of Ginkgo biloba L. - International Journal of Biodiversity and Conservation 3(4): 142-146.

[17] Pop, T. I., Pamfil, D., Bellini, C. (2011): Auxin control in the formation of adventitious roots. - Notulae Botanicae Horti Agrobotanici Cluj-Napoca 39(1): 307-316.

[18] Rahbin, A., Aboutalebi, A., Hasanzadeh, H. (2012): Evaluation the effect of cultural media and IBA on rooting characters of night jessamine (Cestrum nocturnum) stem cutting. - Journal of Applied and Basic Sciences 3(11): 2258-2261.

[19] Rashid, M. H. U., Asif, M., Farooq, T. H., Gautam, N. P., Nawaz, M. F., Ahmad, I., Gilani, M. M., Wu, P. (2018): Cuttings growth response of Dalbergia sissoo (shisham) to soil compaction stress. - Applied Ecology and Environmental Research 17(1): 10491059.

[20] Ray, S. S., Ali, M. N. (2017): Factors affecting macropropagation of bamboo with special reference to culm cuttings: a review update. - New Zealand Journal of Forestry Science 47(1): 17.

[21] Ray, S. S., Ali, M. N. (2016): Evaluation of inexpensive bedding materials for culm cutting of Bambusa balcooa Roxb. and its field performance. - J Biotechnol Biomater 6(227): 2.

[22] Reena, J., Tewari, S. K., Kaushal, R., Tewari, L. (2012): Rooting behaviour of Bambusa balcooa Roxb. in relation to season, age and growing conditions. - Indian Forester 138(1): 79-83.

[23] Saharia, U. K., Sen, S. K. (1990): Optimum age of bamboo culms for nodal cuttings. Indian Forester 116(10): 780-784.

[24] Senyanzobe, J. M. V., Rono, J., Mukanyamwasa, G., Nizeyimana, F., Mukagakwaya, G., de Dieu, R. R. J. (2013): Growth of Bambusa vulgaris and Araundinaria alpina under different nursery site conditions at the higher institute of agriculture and animal husbandry, Northern Rwanda. - Journal of Biodiversity and Environmental Sciences (JBES) 3(9): 9-14.

[25] Sevik, H., Cetin, M. (2016): Effects of some hormone applications on germination and morphological characters of endangered plant species Lilium artvinense L. onion scales. Bulgarian Chemical Communications 48(2): 256-260.

[26] Sevik, H., Guney, K. (2013): Effects of IAA, IBA, NAA, and GA3 on rooting and morphological features of Melissa officinalis L. stem cuttings. - The Scientific World Journal. https://doi.org/10.1155/2013/909507.

[27] Singh, B., Yadav, R., Bhatt, B. P. (2012): Vegetative propagation of Dalbergia sissoo: effect of growth regulators, length, position of shoot and type of cuttings on rooting potential in stem cuttings. - Forestry Studies in China 14(3): 187-192.

[28] Singh, S., Yadav, S., Patel, P. K., Ansari, S. A. (2011): Adventitious rhizogenesis in Bambusa nutans and Bambusa tulda: influence of seasonal variation, IBA and cutting type. - Journal of Forestry Research 22(4): 693. 
[29] Sorin, C., Bussell, J. D., Camus, I., Ljung, K., Kowalczyk, M., Geiss, G., Bellini, C. (2005): Auxin and light control of adventitious rooting in Arabidopsis require ARGONAUTE1. - The Plant Cell 17(5): 1343-1359.

[30] Štefančič, M., Štampar, F., Osterc, G. (2005): Influence of IAA and IBA on root development and quality of Prunus' GiSelA 5'leafy cuttings. - HortScience 40(7): 20522055.

[31] Trobec, M., Štampar, F., Veberič, R., Osterc, G. (2005): Fluctuations of different endogenous phenolic compounds and cinnamic acid in the first days of the rooting process of cherry rootstock 'GiSelA 5' leafy cuttings. - Journal of Plant Physiology 162(5): 589-597. 